\title{
Neuromedin U directly stimulates growth of cultured rat calvarial osteoblast-like cells acting via the NMU receptor 2 isoform
}

\author{
MARCIN RUCINSKI, AGNIESZKA ZIOLKOWSKA, MARIANNA TYCZEWSKA, \\ MARTA SZYSZKA and LUDWIK K. MALENDOWICZ \\ Department of Histology and Embryology, Poznan University of Medical Sciences, \\ 6 Swiecicki St., 60-781 Poznan, Poland
}

Received April 4, 2008; Accepted June 2, 2008

DOI: 10.3892/ijmm_00000031

\begin{abstract}
The neuromedin U (NMU) system is composed of NMU, neuromedin S (NMS) and their receptors NMUR1 and NMUR2. This system is involved in the regulation of energy homeostasis, neuroendocrine functions, immune response, circadian rhythm and spermatogenesis. The present study aimed to investigate the possible role of the NMU system in regulating functions of cultured rat calvarial osteoblast-like (ROB) cells. By using QPCR, high expression of NMU mRNA was found in freshly isolated ROB cells while after 7 , 14, and 21 days of culture, expression of the studied gene was very low. In contrast, NMUR2 mRNA expression in freshly isolated ROB cells was negligible and very high in cultured cells. The highest NMUR2 mRNA expression was observed at day 7, and was followed by lower levels at days 14 and 21 of culture. Neither NMS nor NMUR1 mRNA was found in studied cells. Exposure of cultured ROB cells to NMU8 at concentrations $10^{-6}$ to $10^{-10} \mathrm{M}$ had no effect on expression levels of the genes. During the entire culture period, NMU8 did not affect osteocalcin production, but stimulated proliferative activity of ROB cells at days 14 and 21 of culture. Thus, we demonstrated that cultured rat calvarial osteoblast-like cells are provided with NMUR2, the receptor isoform typical for the central nervous system. Acting via this receptor NMU8 stimulates proliferation of cultured cells and has no effect on their differentiated function (osteocalcin secretion).
\end{abstract}

\section{Introduction}

Recent experimental data suggest that both bone formation and bone remodelling are regulated by numerous factors acting via endocrine, paracrine or autocrine routes and through the

Correspondence to: Professor Ludwik K. Malendowicz, Department of Histology and Embryology, Poznan University of Medical Sciences, 6 Swiecicki St., 60-781 Poznan, Poland E-mail:1km@amp.edu.pl

Key words: neuromedin U, neuromedin S, neuromedin U receptor, QPCR, osteocalcin, proliferation, rat osteoblasts, cell culture nervous system. Among others, peptides involved in regulation of energy homeostasis belong to this group of compounds (1-3), and the best recognised is leptin, an adipocyte-derived anorexigenic hormone, which plays a role in regulating bone formation. Acting directly this pleiotropic cytokine exerts a stimulatory effect on bone formation. While acting through the central nervous system (CNS) leptin suppresses bone formation (4-10). Moreover, OB-Rb mRNA is expressed in osteoblasts, and in vitro leptin enhances their proliferation and has no effect on osteocalcin and osteopontin production by cultured cells $(6,11-13)$.

In contrast to leptin, ghrelin, a stomach-derived orexigenic hormone, exerts opposite effects on appetite, energy expenditure and weight control. Both at the mRNA and protein levels, GHS-R1a was found to be present in osteoblast-like cells and ghrelin directly stimulates proliferation and differentiation and has no effect, inhibitory or otherwise, on apoptosis of osteoblasts (14-18).

In search of novel neuropeptides involved in the regulation of energy homeostasis and bone physiology, we recently demonstrated that orexins (OXs), potent orexigenic peptides, might be involved in the regulation of osteoblast function. In rat calvarial osteoblast-like cultured cells (ROB) we identified OX1-R, but not OX2-R and pre/pro-orexin mRNA. This suggests a physiological role of OXs in regulating osteoblast activity (19).

Recently, Sato et al (20) reported that neuromedin U (NMU), an anorexigenic neuropeptide, regulates bone mass independently of its regulation of energy metabolism. NMU consists of 23 amino acids, and its C-terminal region, which is essential for the peptide's activity, is highly conserved. Neuromedins U and S (NMS) exert their biological activity through two types of receptors, NMUR1 and NMUR2 (21-28). NMUR1 is a peripheral receptor while NMUR2 is predominantly expressed in the CNS. Both NMU and its receptors are barely detectable in bone, and NMU exerts no effect on proliferation and differentiation of cultured calvarial osteoblasts obtained from WT and $\mathrm{Nmu}^{-/-}$mice (20). Since $\mathrm{Nmu}^{-/-}$mice have a higher bone mass than their WT counterparts, their cultured osteoblasts are not affected by NMU. Sato et al (20) suggest that NMU effects on bone formation are mediated via the CNS. Unexpectedly, in search of neuropeptides affecting osteoblast function, we found that cultured ROB cells are provided with neuromedin U receptor, 
Table I. PCR and real-time PCR analyses of mRNA of neuromedin U (NMU), neuromedin S (NMS) and their receptors (NMUR1 and NMUR2) and of the reference gene (HPRT). ${ }^{\mathrm{a}}$

\begin{tabular}{|c|c|c|c|c|c|}
\hline cDNA & Genbank accession no. & Primer & Primer sequence $\left(5^{\prime}-3^{\prime}\right)$ & Position & PCR product size $(\mathrm{bp})$ \\
\hline \multirow[t]{2}{*}{ NMU } & \multirow[t]{2}{*}{ NM 022239} & $\mathrm{~S}$ & GCTTTAACACCCGCACAACA & $50-69$ & \multirow[t]{2}{*}{200} \\
\hline & & A & TGAGGCGATATTGGCGTACC & $230-249$ & \\
\hline \multirow[t]{2}{*}{ NMS } & \multirow[t]{2}{*}{ NM 001012233} & $\mathrm{~S}$ & AGTTTGCTCCCGTCCATC & 276-293 & \multirow[t]{2}{*}{190} \\
\hline & & A & TTGTCAGTGTATCTTCCATTCC & 444-465 & \\
\hline \multirow{2}{*}{ NMUR1 } & \multirow[t]{2}{*}{ NM 023100} & $\mathrm{~S}$ & ATGCTCTCCCCAAATGCTTC & $1-20$ & \multirow[t]{2}{*}{190} \\
\hline & & A & CCAGAGTGCCCACTACGAA & $172-190$ & \\
\hline \multirow[t]{2}{*}{ NMUR2 } & \multirow[t]{2}{*}{ NM 022275} & $\mathrm{~S}$ & GAATCCCTTGAGGCGAACA & $841-859$ & \multirow[t]{2}{*}{137} \\
\hline & & A & CTGAAGAAGAGCCGGTCCAC & 958-977 & \\
\hline \multirow[t]{2}{*}{ HPRT } & \multirow[t]{2}{*}{ NM 012583} & $\mathrm{~S}$ & CAGTCAACGGGGGACATAAAAG & $391-412$ & \multirow[t]{2}{*}{146} \\
\hline & & A & ATTTTGGGGCTGTACTGCTTGA & $515-536$ & \\
\hline
\end{tabular}

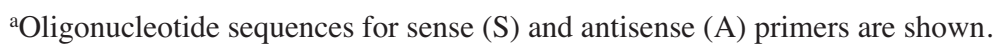

and we revealed a direct effect of NMU on their proliferative activity.

\section{Materials and methods}

Chemicals. Neuromedin U8 (NMU8) was purchased from Bachem Feinchemikalien AG. Bubbendorf, Switzerland. If not otherwise stated, the remaining reagents were obtained from Sigma-Aldrich or POCh (Gliwice, Poland).

Primary rat calvarial osteoblast-like ( $R O B$ ) cell cultures. The technique used, was that previously described (29-33) with a few modifications. Briefly, calvarials of eight 2-day-old rats were placed in DMEM (Gibco, UK), and the connective tissue was removed. Calvarials were then cut into small fragments, which were dissociated to cell suspensions by enzymatic digestion with $0.1 \%$ collagenase-I (Sigma-Aldrich) for $30 \mathrm{~min}$ at $37^{\circ} \mathrm{C}$. ROB cells were harvested by centrifugation and resuspended in DMEM supplemented with $\mathrm{NaHCO}_{3}, 6 \%$ FCS (fetal calf serum) and antibioticantimycotic solution. Cells were then plated in culture dishes $\left(10^{4}\right.$ cells/dish), and cultured for 21 days at $37^{\circ} \mathrm{C}$ in a humidified atmosphere of $95 \%$ air- $5 \% \mathrm{CO}_{2}$, with the medium being changed every other day (34). The cells in culture were confirmed to be osteoblasts both by morphology and osteonectin and collagen-1 $\alpha$ expression (19). The local Ethics Commitee for Animal Studies approved the study protocol.

The experiments were performed on freshly isolated cells. Cells were harvested at days 7, 14 and 21 of culture, $48 \mathrm{~h}$ before sampling, cells were maintained in medium without FCS. In such medium osteoblasts were exposed for $48 \mathrm{~h}$ to various concentrations of neuromedin U8.

Osteocalcin determination. Osteocalcin concentrations in the culture medium were estimated using a rat osteocalcin EIA kit (Biomedical Technologies Inc., Stoughton, MA, USA). The sensitivity of the assay was $0.5 \mathrm{ng} / \mathrm{ml}$, and inter- and intraassay CVs were 7 and $4 \%$, respectively.
Cell proliferation. Proliferation rate of ROB cells was measured using the EZ4U Nonradioactive Cell Proliferation and Cytotoxic Assay (Biomedica, Vienna, Austria) (35). Cultured cells were incubated for 90 min with EZ4U, and formazan derivative production, which is linearly related to the cell number, was measured at $490 \mathrm{~nm}$ wavelength in a microplate autoreader EL-13 (Bio-Tek Instruments, Winooski, VT, USA). It is important to emphasise that the EZ4U assay system is highly compatible with the standard ${ }^{3} \mathrm{H}$-thymidine incorporation assay.

Conventional RT-PCR and QPCR. ROB cells were harvested, and total RNA was extracted, as previously detailed (32,36-39). Contaminating DNA was eliminated by DNase-I treatment (RNase-Free DNase Set; Promega, Madison, WI, USA), and the amount of total RNA was determined by measuring optical density at $260 \mathrm{~nm}$. Purity was estimated using the 260/280 nm absorption ratio, which was consistently higher than 1.8. RT and was performed using AMV Reverse Transcriptase (Promega, USA) with Oligo dT (PE Biosystems, Warrington, UK) as primers. Conventional and semiquantitative real-time PCR were carried out in a Roche LightCycler 2.0 (Roche, Mannheim, Germany), as previously described, $(38,39)$. Primers were designed using Primer 3 software (Whitehead Institute for Biomedical Research, Cambridge, MA, USA) (Table I). They were purchased from the Laboratory of DNA Sequencing and Oligonucleotide Synthesis, Institute of Biochemistry and Biophysics, Polish Academy of Sciences, Warsaw.

For conventional $\mathrm{PCR}$, the amplification program included a denaturation step $\left(94^{\circ} \mathrm{C}\right.$ for $\left.10 \mathrm{~min}\right)$, and 35 cycles of three-step amplification (denaturation, $94^{\circ} \mathrm{C}$ for $30 \mathrm{sec}$; annealing, $57^{\circ} \mathrm{C}$ for $60 \mathrm{sec}$; and extension, $68^{\circ} \mathrm{C}$ for $120 \mathrm{sec}$ ). A final extension step at $68^{\circ} \mathrm{C}$ for 7 min was then carried out. Detection of the PCR amplicons was performed by size fractionation on $2 \%$ agarose gel electrophoresis. To eliminate the possibility of amplifying genomic DNA, in some experiments PCR was carried out without prior RT of the 

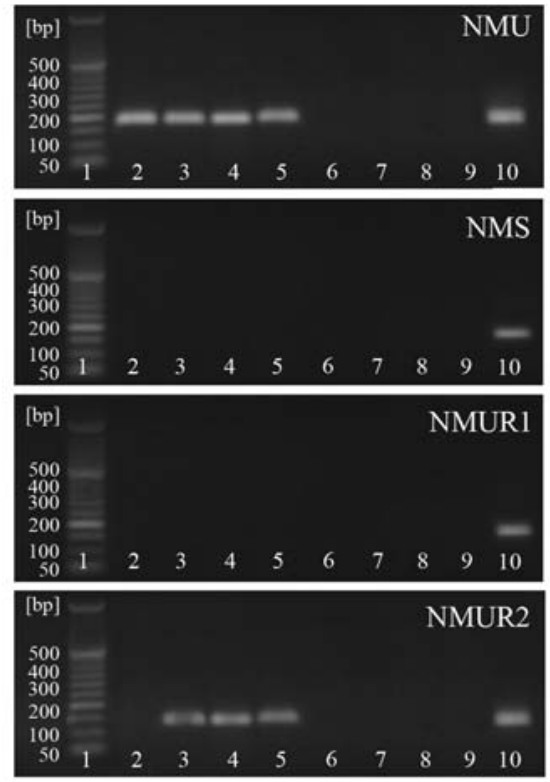

Figure 1. Ethidium bromide-stained $2 \%$ agarose gel showing cDNA amplified with rat NMU-, NMS-, NMUR1- and NMUR2-specific primers from RNA of ROB cells cultured for 7, 14 and 21 days and of freshly isolated cells. Lane 1, $200 \mathrm{ng}$ of a DNA size marker (50 bp DNA Ladder; MBI Fermentas, Vilnius, Lithuania); lane 2, freshly isolated cells; lanes 3-5, days 7, 14 and 21 of culture. Respective negative controls (no RT of the RNA) are shown in lanes 6-9. Lane 10, positive control organs (hypothalamus for NMS and adrenal cortex for NMUR1) Specific primers amplified a single band of the expected length: NMU, 200 bp; NMS, 190 bp; NMUR1, 190 bp, and NMUR2, $137 \mathrm{bp}$.

RNA. For QPCR, the following program involved, a denaturation step $\left(95^{\circ} \mathrm{C}\right.$ for $\left.10 \mathrm{~min}\right)$, and 45 cycles of threestep amplification (denaturation, $95^{\circ} \mathrm{C}$ for $10 \mathrm{sec}$; annealing, $58^{\circ} \mathrm{C}$; and extension, $72^{\circ} \mathrm{C}$ for $4 \mathrm{sec}$ ). Subsequently, melting curve $\left(60-90^{\circ} \mathrm{C}\right.$ with heating rate of $\left.0.1^{\circ} \mathrm{C} / \mathrm{sec}\right)$ was performed to check the specificity of amplification and the presence of by-products. All samples were amplified in duplicate, and the HPRT (hypoxanthine-guanine phosphoribosyl transferase) gene was used as reference to normalize data.

Statistics. Data were expressed as the mean \pm SEM and the statistical comparison was conducted by the unpaired Student's t-test.

\section{Results}

$N M U, N M S$ and their receptor expression in ROB cells. Standard RT-PCR revealed expression of specific mRNA for NMU in freshly isolated ROB cells which were cultured for 7, 14 and 21 days (Fig. 1). Significantly, NMUR2 mRNA was found only in cultured, but not in freshly isolated cells. In all assays reaction products were of the expected length. In contrast, neither NMS nor NMUR1 mRNA were found in studied cells, while in positive control organs (hypothalamus and adrenal cortex, respectively) expression of the genes was apparent.

By means of QPCR, high expression of NMU mRNA was found in freshly isolated ROB cells while after 7, 14, and 21 days of culture, expression of the studied gene was very low (Fig. 2). In contrast, NMUR2 mRNA expression in

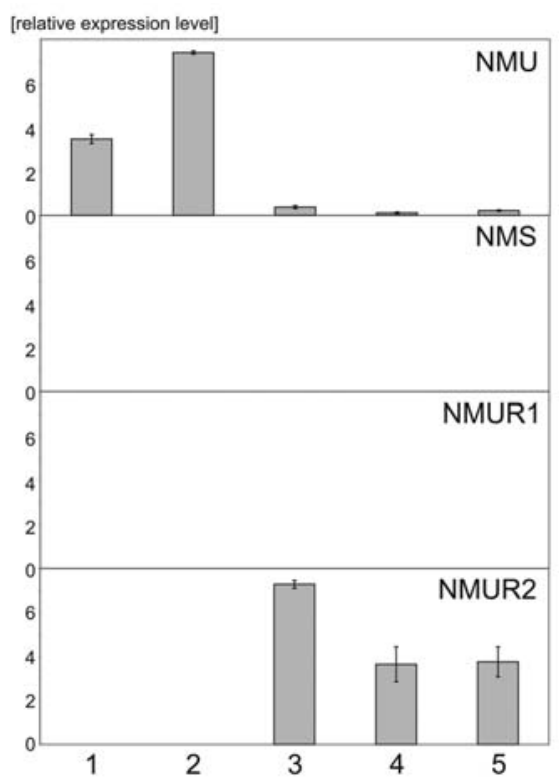

Figure 2. QPCR analyses of NMU, NMS, NMUR1 and NMUR2 gene expression in the ROB cells at days 7, 14 and 21 of culture and in freshly isolated cells (day 0). All samples were amplified in triplicates, and HPRT gene expression was used as reference to normalize data. In each group $n=3$. Bars represent means and SE. Lines: 1, rat calvaria bone; 2, freshly isolated bone cells; 3 , day 7 of culture; 4 , day 14 of culture; 5 , day 21 of culture.

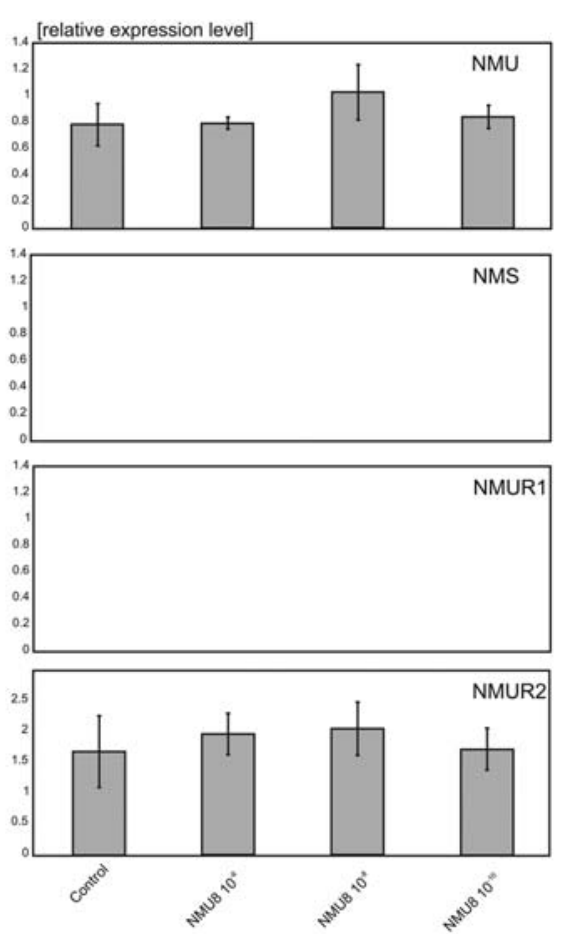

Figure 3. QPCR analysis of NMUR2 gene expression in ROB cells cultured in the presence of different concentrations of NMU8.

freshly isolated ROB cells was negligible and very high in cultured cells. The highest NMUR2 mRNA expression was observed at day 7, and was followed by lower levels at days 14 and 21 of culture. Similar to standard RT-PCR, neither NMS nor NMUR1 mRNA were detected in QPCR. 

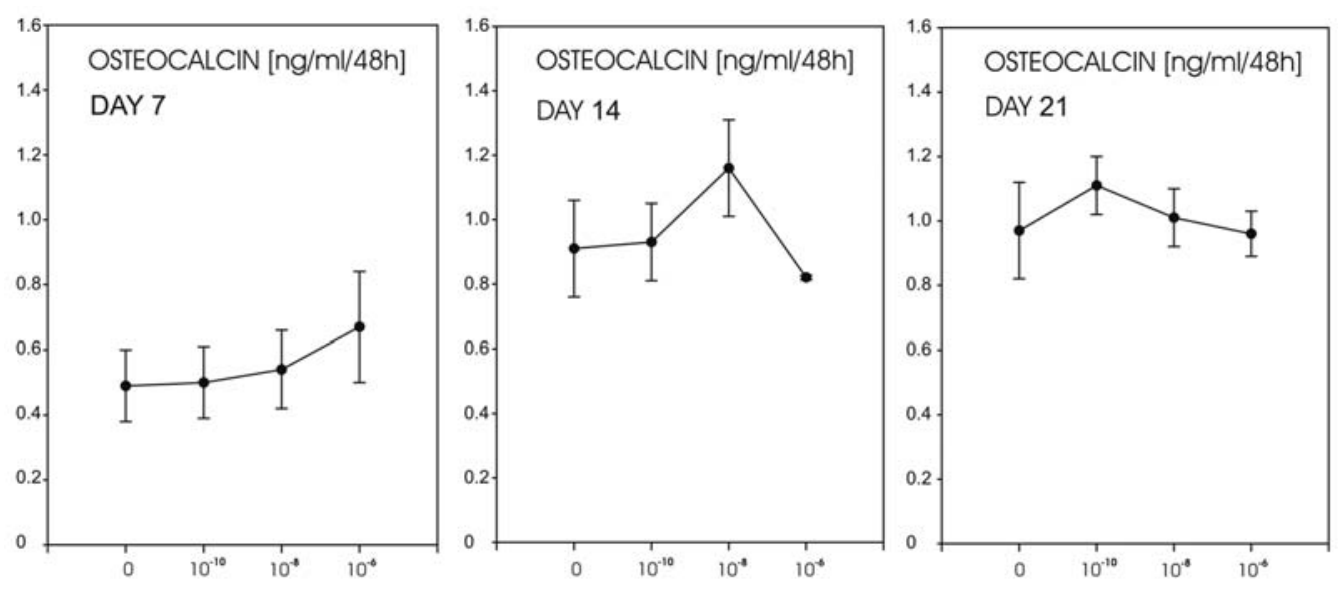

$\mathrm{NMU}$

Figure 4. Effect of NMU on osteocalcin secretion by cultured ROB cells. Cells were exposed to different concentrations of NMU8 ( $1 \times 10^{-10}$ to $\left.1 \times 10^{-6} \mathrm{M}\right)$ for $48 \mathrm{~h}$. Neuropeptide was added to the culture $48 \mathrm{~h}$ before medium collecting at days 7, 14 and 21. Data are expressed as means \pm SEM, $\mathrm{n}=8$. Statistical comparisons (in relation to control) were performed by the unpaired Student's t-test: ${ }^{*} \mathrm{p}<0.05,{ }^{* *} \mathrm{p}<0.02,{ }^{* * * *} \mathrm{p}<0.01,{ }^{* * * *} \mathrm{p}<0.001$.
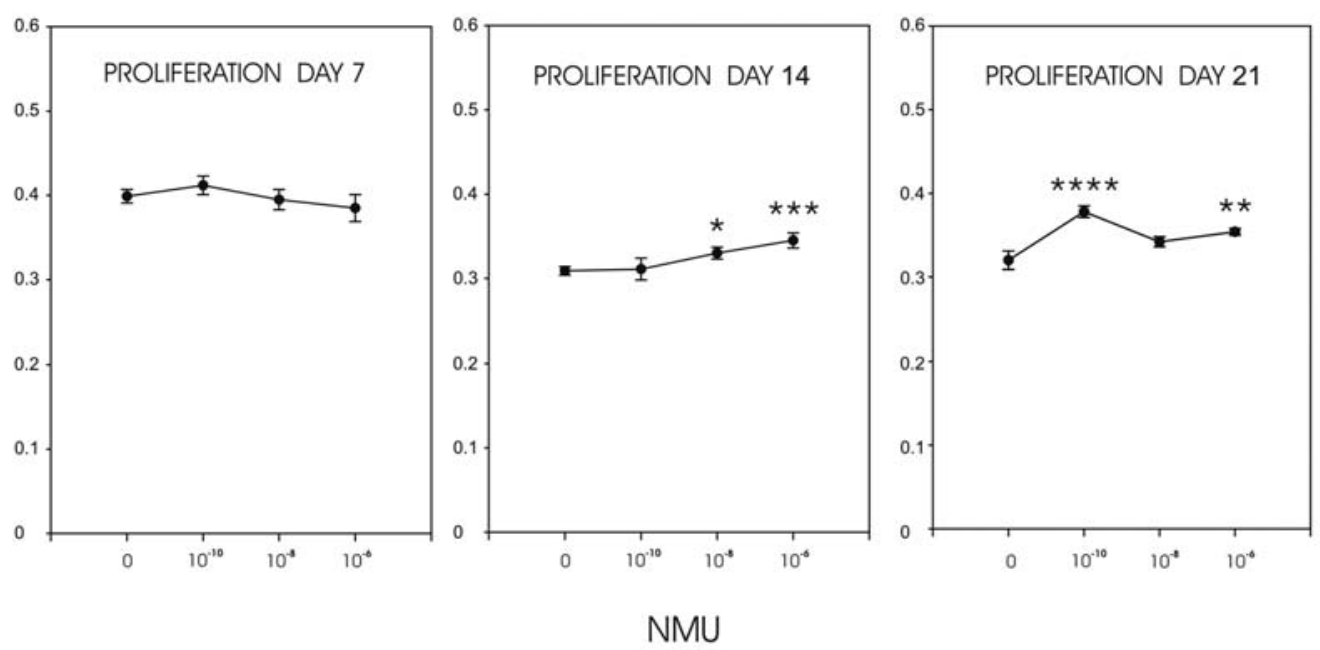

Figure 5. Effect of NMU on proliferative activity of cultured ROB cells. Cells were exposed to different concentrations of NMU8 (1x10-10 to $\left.1 \times 10^{-6} \mathrm{M}\right)$ for $48 \mathrm{~h}$. Neuropeptide was added to the culture $48 \mathrm{~h}$ before medium collecting at days 7, 14 and 21. Data are expressed as means $\pm \mathrm{SEM}, \mathrm{n}=8$. Statistical comparisons of means in relation to control groups were performed by the unpaired Student's t-test: ${ }^{*} \mathrm{p}<0.05,{ }^{* *} \mathrm{p}<0.02,{ }^{* * *} \mathrm{p}<0.01,{ }^{* * * *} \mathrm{p}<0.001$.

To ascertain whether there was an interrelationship between NMU concentration and NMUR2 gene expression, ROB cells were cultured at days 6 and 7 in the presence of different concentrations of NMU8. Two days exposure of cultured ROB cells to NMU8 at concentrations $10^{-6}$ to $10^{-10} \mathrm{M}$ had no effect on expression levels of studied genes (Fig. 3).

Osteocalcin production. To investigate whether NMU8 affects osteocalcin production, cultured ROB cells were exposed for $48 \mathrm{~h}$ to various concentrations of the neuropeptide. When compared with day 7 , osteocalcin concentration in the medium was higher at days 14 and 21 of culture (Fig. 4). During the entire culture period NMU8 did not affect osteocalcin production by the studied cells.

Cell proliferation. At days 14 and 21 of culture, proliferation rates of ROB cells were lower than at day 7 (Fig. 5). NMU8 exposure for $48 \mathrm{~h}$ significantly stimulated ROB cell proliferation at days 14 and 21 but was ineffective at day 7 .

\section{Discussion}

In the rat both NMU and NMS exert potent anorexigenic effects, which in part are mediated via CRH neurons $(26-28,40)$. It appears that NMU is also involved in bone remodelling. In search of neuropeptides involved in both regulation of energy homeostasis and bone physiology Sato et al (20) demonstrated that NMU controls bone remodelling in the mouse via CNS. Furthermore, they suggest that NMU may be a central mediator of leptin-dependent regulation of bone mass. By means of in situ hybridization they found that NMU and its receptors were barely detectable in the bone of WT and $\mathrm{Nmu}^{-/}$mice and 'both WT and $\mathrm{Nmu}^{-/}$osteoblasts proliferated normally in vitro in response to NMU treatment'. 
In contrast with the above cited data we found that cultured rat calvarial osteoblast-like cells express NMUR2, a central nervous type of NMU receptor, but not NMUR1, a peripheral one. In this context it is worth noting that in freshly isolated cells we could not identify NMUR2 mRNA.

This finding confirms observations of Sato et al (20) on negligible expression of NMU receptors in in situ osteoblasts. Furthermore, this intriguing observation leads to further investigation as to why NMUR2 receptor is expressed in cultured but not in freshly isolated osteoblasts. It could be speculated that NMUR2 expression is a marker of osteoblast differentiation.

This assumption, however, is restricted by the following facts: i) osteoblasts in situ are not provided with that receptor (20) and ii) the highest expression of the NMUR2 gene is observed in the proliferative stage of osteoblast culture (day 7). An alternative explanation may be that in the bone, local factors of the microenvironment (haematopoietic stem cell niche or the osteoblastic niche) suppress expression of NMUR2 in osteoblasts (41-43). This possibility implies that such factors would be removed during isolation of rat calvarial osteoblasts.

One of the environmental factors involved in regulation of NMUR2 gene expression in osteoblasts could be the NMU. In our experiments expression of the NMU gene was very high in freshly isolated ROB cells and absent in cultured cells. This finding suggests that isolated from calvarials of newborn rats NMU mRNA expressing cells undergo elimination in the course of long-term culture. It is still unclear whether NMU suppresses NMUR2 expression in osteoblasts. To investigate such a possibility we added various concentrations of NMU into medium of cultured ROB cells and such exposure did not affect the expression levels of the studied genes.

To assess whether NMU affects ROB cell differentiation, we measured osteocalcin [a late osteoblastic differentiation marker (44)] concentrations in culture medium. Exposure of cultured cells to various NMU concentrations had no effect on osteocalcin secretion. This finding confirms observations of Sato et al (20) regarding the lack of NMU effect on osteocalcin secretion by cultured osteoblasts isolated from either WT or $\mathrm{Nmu}^{-/}$mice. However, in contrast with their data we found that NMU stimulates proliferation of cultured ROB cells and this effect was observed at days 14 and 21 of culture but not in the proliferative stage of culture (day 7). Whether this finding is of physiological relevance remains unclarified.

Thus, results of the present study are the first demonstration that cultured rat calvarial osteoblast-like cells express NMUR2. Moreover, we found that NMU8, acting probably through NMUR2, stimulates proliferation of cultured cells and has no effect on their differentiating functions.

\section{References}

1. Manolagas SC: Birth and death of bone cells: Basic regulatory mechanisms and implications for the pathogenesis and treatment of osteoporosis. Endocr Rev 21: 115-137, 2000.

2. Harada S and Rodan GA: Control of osteoblast function and regulation of bone mass. Nature 423: 349-355, 2003.

3. Elefteriou F: Neuronal signaling and the regulation of bone remodeling. Cell Mol Life Sci 62: 2339-2349, 2005.
4. Ducy P, Amling M, Takeda S, Priemel M, Schilling AF, Beil FT, Shen J, Vinson C, Rueger JM and Karsenty G: Leptin inhibits bone formation through a hypothalamic relay: a central control of bone mass. Cell 100: 197-207, 2000.

5. Takeda S: Central control of bone remodelling. Biochem Biophys Res Commun 328: 697-699, 2005.

6. Cornish J, Callon KE, Bava U, Lin C, Naot D, Hill BL, Grey AB, Broom N, Myers DE, Nicholson GC and Reid IR: Leptin directly regulates bone cell function in vitro and reduces bone fragility in vivo. J Endocrinol 175: 405-415, 2002.

7. Gordeladze JO and Reseland JE: A unified model for the action of leptin on bone turnover. J Cell Biochem 88: 706-712, 2003.

8. Thomas T: The complex effects of leptin on bone metabolism through multiple pathways. Curr Opin Pharmacol 4: 295-300, 2004.

9. Hamrick MW, Della-Fera MA, Choi YH, Pennington C, Hartzell D and Baile CA: Leptin treatment induces loss of bone marrow adipocytes and increases bone formation in leptindeficient ob/ob mice. J Bone Miner Res 20: 994-1001, 2005.

10. Karsenty G: Convergence between bone and energy homeostases: leptin regulation of bone mass. Cell Metab 4: 341-348, 2006.

11. Gordeladze JO, Drevon CA, Syversen U and Reseland JE: Leptin stimulates human osteoblastic cell proliferation, de novo collagen synthesis, and mineralization: Impact on differentiation markers, apoptosis, and osteoclastic signaling. J Cell Biochem 85: 825-836, 2002.

12. Lee YJ, Park JH, Ju SK, You KH, Ko JS and Kim HM: Leptin receptor isoform expression in rat osteoblasts and their functional analysis. FEBS Lett 528: 43-47, 2002.

13. Iwamoto I, Fujino T and Douchi T: The leptin receptor in human osteoblasts and the direct effect of leptin on bone metabolism. Gynecol Endocrinol 19: 97-104, 2004.

14. Belloni AS, Macchi C, Rebuffat P, Conconi MT, Malendowicz LK, Parnigotto PP and Nussdorfer GG: Effect of ghrelin on the apoptotic deletion rate of different types of cells cultured in vitro. Int J Mol Med 14: 165-167, 2004.

15. Fukushima N, Hanada R, Teranishi H, Fukue Y, Tachibana T, Ishikawa H, Takeda S, Takeuchi Y, Fukumoto S, Kangawa K, Nagata K and Kojima $\mathrm{M}$ : Ghrelin directly regulates bone formation. J Bone Miner Res 20: 790-798, 2005.

16. Kim SW, Her SJ, Park SJ, Kim D, Park KS, Lee HK, Han BH, Kim MS, Shin CS and Kim SY: Ghrelin stimulates proliferation and differentiation and inhibits apoptosis in osteoblastic MC3T3-E1 cells. Bone 37: 359-369, 2005.

17. Maccarinelli G, Sibilia V, Torsello A, Raimondo F, Pitto M, Giustina A, Netti C and Cocchi D: Ghrelin regulates proliferation and differentiation of osteoblastic cells. J Endocrinol 184: 249-256, 2005.

18. Delhanty PJ, van der Eerden BC, van der Velde M, Gauna C, Pols HA, Jahr H, Chiba H, van der Lely AJ and van Leeuwen JP: Ghrelin and unacylated ghrelin stimulate human osteoblast growth via mitogen-activated protein kinase (MAPK)/ phosphoinositide 3-kinase (PI3K) pathways in the absence of GHS-R1a. J Endocrinol 188: 37-47, 2006.

19. Ziolkowska A, Rucinski M, Tortorella C, Tyczewska M, Nussdorfer GG and Malendowicz LK: Cultured rat calvarial osteoblast-like cells are provided with orexin type 1 receptors. Int J Mol Med 20: 779-782, 2007.

20. Sato S, Hanada R, Kimura A, Abe T, Matsumoto T, Iwasaki M, Inose H, Ida T, Mieda M, Takeuchi Y, Fukumoto S, Fujita T, Kato S, Kangawa K, Kojima M, Shinomiya K and Takeda S: Central control of bone remodeling by neuromedin U. Nat Med 13: 1234-1240, 2007.

21. Kojima M, Maruno R, Nakazato M, Date Y, Murakami N, Hanada R, Matsuo $\mathrm{H}$ and Kangawa K: Purification and identification of neuromedin $U$ as an endogenous ligand for an orphan receptor GPR66 (FM3). Biochem Biophys Res Commun 276: 435-438, 2000 .

22. Howard AD, Wang R, Pong SS, Mellin TN, Strack A, Guan XM, Zeng Z, Williams DLJ, Feighner SD, Nunes CN, Murphy B, Stair JN, Yu H, Jiang Q, Clements MK, Tan CP, McKee KK, Hreniuk DL, McDonald TP, Lynch KR, Evans JF, Austin CP, Caskey CT, Van der Ploeg LH and Liu Q: Identification of receptors for neuromedin $U$ and its role in feeding. Nature 406: 70-74, 2000.

23. Ozaki Y, Onaka T, Nakazato M, Saito J, Kanemoto K, Matsumoto $\mathrm{T}$ and Ueta $\mathrm{Y}$ : Centrally administered neuromedin $\mathrm{U}$ activates neurosecretion and induction of C-Fos messenger ribonucleic acid in the paraventricular and supraoptic nuclei of rat. Endocrinology 143: 4320-4329, 2002. 
24. Ueta Y, Ozaki Y and Saito J: Novel G-protein coupled receptor ligands and neurohypophysial hormones. J Neuroendocrinol 16: 378-382, 2004.

25. Brighton PJ, Szekeres PG and Willars GB: Neuromedin U and its receptors: structure, function, and physiological roles. Pharmacol Rev 56: 231-248, 2004.

26. Ida T, Mori K, Miyazato M, Egi Y, Abe S, Nakahara K, Nishihara M, Kangawa K and Murakami N: Neuromedin S is a novel anorexigenic hormone. Endocrinology 146: 4217-4223, 2005.

27. Mori K, Miyazato M, Ida T, Murakami N, Serino R, Ueta Y, Kojima $M$ and Kangawa $K$ : Identification of neuromedin $S$ and possibile role in the mammalian circadian oscillator system. EMBO J 24: 325-335, 2005

28. Shousha S, Nakahara K, Sato M, Mori K, Miyazato M, Kangawa $\mathrm{K}$ and Murakami N: Effect of neuromedin $\mathrm{S}$ on feeding regulation in the Japanese quail. Neurosci Lett 391: 87-90, 2006.

29. Boden SC, McCuaig K, Hair G, Racine M, Titus L, Wozney JM and Nanes MS: Differential effects and glucocorticoid potentiation of bone morphogenetic protein action during rat osteoblast differentiation in vitro. Endocrinology 137: 3401-3407, 1996.

30. Bodine PV and Komm BS: Tissue culture models for studies of hormone and vitamin action in bone cells. Vitam Horm 64: 101-151, 2002.

31. Kartsogiannis $\mathrm{V}$ and $\mathrm{Ng} \mathrm{KW}$ : Cell lines and primary cell cultures in the study of bone cell biology. Mol Cell Endocrinol 228: 79-102, 2004.

32. Ziolkowska A, Rucinski M, Di Liddo R, Nussdorfer GG and Malendowicz LK: Expression of the beacon gene in endocrine glands of the rat. Peptides 25: 133-137, 2004.

33. Ziolkowska A, Carraro G, Rebuffat P, Spinazzi R, Nussdorfer GG, Rucinski M and Malendowicz LK: Beacon [47-73] inhibits glucocorticoid secretion and growth of cultured rat and human adrenocortical cells. Int J Mol Med 14: 457-461, 2004.

34. Ziolkowska A, Rucinski M, Pucher A, Tortorella C, Nussdorfer GG and Malendowicz LK: Expression of osteoblast marker genes in rat calvarial osteoblast-like cells, and effects of the endocrine disrupters diphenylolpropane, benzophenone-3, resveratrol and silymarin. Chem Biol Interact 164: 147-156, 2006.
35. Mosmann T: Rapid colorimetric assay for cellular growth and survival: application to proliferation and cytotoxicity assays. J Immunol Methods 65: 55-63, 1983.

36. Albertin G, Carraro G, Parnigotto PP, Conconi MT, Ziolkowska A, Malendowicz LK and Nussdorfer GG: Human skin keratinocytes and fibroblasts express adrenomedullin and its receptors, and adrenomedullin enhances their growth in vitro by stimulating proliferation and inhibiting apoptosis. Int J Mol Med 11: 635-639, 2003.

37. Tortorella C, Macchi C, Spinazzi R, Malendowicz LK, Trejter M and Nussdorfer GG: Ghrelin, an endogenous ligand for the growth hormone-secretagogue receptor, is expressed in the human adrenal cortex. Int J Mol Med 12: 213-217, 2003.

38. Rucinski M, Andreis PG, Ziolkowska A, Nussdorfer GG and Malendowicz LK: Differential expression and function of beacon in the rat adrenal cortex and medulla. Int J Mol Med 16: 35-40, 2005.

39. Rucinski M, Ziolkowska A, Neri G, Trejter M, Zemleduch T, Tyczewska M, Nussdorfer GG and Malendowicz LK: Expression of neuromedins $\mathrm{S}$ and $\mathrm{U}$ and their receptors in the hypothalamus and endocrine glands of the rat. Int J Mol Med 20: 255-259, 2007.

40. Miyazato M, Mori K, Ida T, Kojima M, Murakami N and Kangawa K: Identification and functional analysis of a novel ligand for $\mathrm{G}$ protein-coupled receptor, Neuromedin S. Regul Pept 145: 37-41, 2008.

41. Guillotin B, Bourget C, Remy-Zolgadri M, Bareille R, Fernandez P, Conrad V and Amédée-Vilamitjana J: Human primary endothelial cells stimulate human osteoprogenitor cell differentiation. Cell Physiol Biochem 14: 325-332, 2004.

42. Zhu J and Emerson SG: A new bone to pick: osteoblasts and the haematopoietic stem-cell niche. Bioessays 26: 595-599, 2004.

43. Yin $\mathrm{T}$ and $\mathrm{Li} \mathrm{L}$ : The stem cell niches in bone. J Clin Invest 116: 1195-1201, 2006.

44. Sharma P, Solomon KR and Hauschka PV: High-throughput tool for discovery of bone regulating factors. Biotechniques 41 : 539-542, 2006. 